\title{
Electrocambalidae fam. nov., a new family of Cambalidea from Cretaceous Burmese amber (Diplopoda, Spirostreptida)
}

\author{
Leif MORITZ ${ }^{\circledR 1, *} \&$ Thomas WESENER ${ }^{2}$ \\ 1,2 Zoological Research Museum Alexander Koenig (ZFMK), Leibniz Institute for Animal Biodiversity, \\ Adenauerallee 160, D-53113, Bonn, Germany. \\ ${ }^{1}$ Institute of Evolutionary Biology and Ecology, University of Bonn, An der Immenburg 1, \\ 53121 Bonn, Germany. \\ *Corresponding author: moritz.leif@gmail.com \\ 2Email: t.wesener@leibniz-zfmk.de \\ ${ }^{1}$ urn:1sid:zoobank.org:author:89921EE8-F015-4FED-AB5C-1D17F2C2F8F6 \\ ${ }^{2}$ urn:lsid:zoobank.org:author:86DEA7CD-988C-43EC-B9D6-C51000595B47
}

\begin{abstract}
A new family, Electrocambalidae fam. nov. of the suborder Cambalidea is described from Cretaceous Burmese amber based on two new genera, Electrocambala gen. nov. and Kachincambala gen. nov. with four new species, Electrocambala ornata gen. et sp. nov., E. cretacea gen. et sp. nov., Kachincambala muelleri gen. et sp. nov. and $K$. distorta gen. et sp. nov. The specimens are described combining classical light microscopy with drawings and photography, and modern micro-computed tomography $(\mu \mathrm{CT})$. Morphological characters otherwise obscured are examined and visualized by creating volume renderings and 3D-segmentations from $\mu \mathrm{CT}$ data. Electrocambalidae fam. nov. is characterized by the following character combination: (1) a forward shift of leg pair 3, resulting in an apparently legless $3^{\text {rd }}$ body ring, (2) presence of metazonital setae, and (3) extensive pilosity on the head. Although some of these characters are shared with other Juliformia they are unique in this combination. The described fossils are the oldest and first Mesozoic Spirostreptida and Cambalidea known and ca 70 million years older than previous records of the group.
\end{abstract}

Keywords. Myanmar, fossil, micro-CT, gonopods, evolution.

Moritz L. \& Wesener T. 2021. Electrocambalidae fam. nov., a new family of Cambalidea from Cretaceous Burmese amber (Diplopoda, Spirostreptida). European Journal of Taxonomy 755: 22-46.

https://doi.org/10.5852/ejt.2021.755.1397

\section{Introduction}

Millipedes (Diplopoda Gervais, 1844), which comprise more than 11000 described extant species (Sierwald \& Bond 2007; Brewer et al. 2012; Enghoff et al. 2015), were among the first fully terrestrial animals (Selden \& Read 2007; Shear \& Edgecombe 2010; Kenrick et al. 2012), and are as detritivores (Crawford 1992; Cárcamo et al. 2000) and soil-forming organisms (Crossley 1977) essential for terrestrial ecosystems - a role they have played probably unchanged since the Paleozoic (Shear \& Kukalová-Peck 
MORITZ L. \& WESENER T., Electrocambalidae, a new millipede family from Cretaceous amber

1990). From the Paleozoic only representatives of extinct orders are known (Wilson \& Anderson 2004; Wilson 2006), among them the giant Arthropleurida Waterlot, 1934, which could reach a length of up to $2 \mathrm{~m}$ and were the largest land arthropods that ever lived (Edgecombe 2015). For the whole Mesozoic only few millipede fossils are known, which leaves a gap in our knowledge of millipede evolution. Most of the Mesozoic millipede fossils known are from the Cretaceous Burmese amber deposits of Myanmar and can be placed in extant orders (Rasnitsyn \& Golovatch 2004; Liu et al. 2017; Wesener \& Moritz 2018; Jiang et al. 2019; Moritz \& Wesener 2019; Stoev et al. 2019; Su et al. 2020), while only few millipedes are recorded from other Mesozoic deposits (Fritsch 1910; Martynov 1936; Mulleried 1942; Dzik 1975, 1981; Jell 1983; Duy-Jacquemin \& Azar 2004; Shear et al. 2009).

Burmese amber from the Hukawng Valley in Kachin State, Northern Myanmar, has a long history of exploitation (Grimaldi et al. 2002; Cruickshank \& Ko 2003). It is dated to the early Cenomanian age in the Upper Cretaceous ( $98 \pm 0.63$ ma, Shi et al. 2002). In recent years Burmese amber yielded many discoveries and inclusions important for our understanding of arthropod evolution. The oldest known and first Mesozoic fossils of various millipede taxa were found trapped in Burmese amber, like those of the orders Callipodida Pocock, 1894 (Stoev et al. 2019), Platydesmida de Saussure, 1860 (Moritz \& Wesener 2019), Siphoniulida Pocock, 1894 (Liu et al. 2017) and Siphonophorida Newport, 1844 (Jiang et al. 2019). Furthermore, a great diversity of undescribed millipedes has been recorded from Burmese amber, among which are several millipedes belonging to the spirostreptidan taxon Cambalidea Cook, 1895 (Wesener \& Moritz 2018).

Spirostreptida Brandt, 1833 belong to the Juliformia Attems, 1926, millipedes in which sternites, pleurites and tergites are fused completely into a rigid ring (Enghoff 1984; Blanke \& Wesener 2014) (with the exception of some Nemasomatidae Bollman, 1893, which have free sternites on anterior segments (Enghoff 1984)). The relationship of the Spirostreptida to the other two Juliformia taxa, Julida Brandt, 1833 and Spirobolida Bollman, 1893 (Verhoeff 1910; Sierwald \& Bond 2007; Blanke \& Wesener 2014), as well as the internal relationship and the monophyly of the Spirostreptida are controversial (e.g., Jeekel 2004; Korsós \& Johns 2009). Classically, the Spirostreptida are divided into two subgroups, the Spirostreptidea Brandt, 1833 and the Cambalidea (Enghoff et al. 2015). The Cambalidea or "Cambaloidea" (Jeekel 2004), with more than 250 species and 60 genera, have been in a constant flux basically since 1900 (Attems 1900) and their classification and monophyly remains unclear despite efforts by numerous authors (Verhoeff 1932; Mauriès 1977, 1983, 1987, 1992; Hoffman 1980; Shelley 2003, 2007; Jeekel 1985, 2004). Every worker on the group seems to develop their own system of internal classification of the Cambalidea, none of them based on a phylogenetic analysis. The Cambalidea are placed either in an order of its own (Mauriès 1983), as a subgroup of the Spirostreptida (Hoffman 1980; Shelley 2003; Jeekel 2004; Enghoff et al. 2015) or Julida (Mauriès 1977), or split between the Spirostreptida and Julida (Mauriès 1992). Since no classification of the group is based on a phylogenetic analysis, we refrain here from proposing another classification, but follow the system by Jeekel (2004) and Enghoff et al. (2015) which treats all five families (or main groups), the Cambalidae Bollman, 1893, Cambalopsidae Cook, 1895, Choctellidae Chamberlain \& Hoffman, 1950, Iulomorphidae Verhoeff, 1924, and Pseudonannolenidae Silvestri, 1895 of equal rank as part of the order Spirostreptida. Here, we describe a sixth group from Cretaceous amber.

\title{
Material and methods
}

\author{
Abbreviations \\ $\mathrm{BuB}=$ collection number of inclusions in the collection of Patrick Müller \\ $\mathrm{CT}=$ computed tomography \\ ZFMK $=$ Zoological Research Museum A. Koenig, Leibniz Institute for Animal Biodiversity, \\ Bonn, Germany \\ ZFMK-MYR $=$ collection number of the Myriapoda collection at the ZFMK
}


Table 1. Material studied. Abbreviations: $\mathrm{BuB}=$ identifier in the collection of Patrick Müller; $\mathrm{PM}=$ Patrick Müller; ZFMK = Zoological Research Museum A. Koenig; ZFMK-MYR = identifier in the Myriapoda collection of the ZFMK.

\begin{tabular}{llcc}
\hline Species & Specimen & Status & Dep. \\
\hline Electrocambala ornata gen. et sp. nov. & ZFMK-MYR7369 & holotype & ZFMK \\
Electrocambala ornata gen. et sp. nov. & ZFMK-MYR7370 & paratype & ZFMK \\
Electrocambala ornata gen. et sp. nov. & BuB1825 & - & PM \\
Electrocambala ornata gen. et sp. nov. & BuB1962 & - & PM \\
Electrocambala cretacea gen. et sp. nov. & ZFMK-MYR7370 & holotype & ZFMK \\
Electrocambala sp. & BuB1990 & - & PM \\
Kachincambala distorta gen. et sp. nov. & ZFMK-MYR7368 & holotype & ZFMK \\
Kachincambala muelleri gen. et sp. nov. & ZFMK-MYR10225 & holotype & ZFMK \\
Kachincambala sp. & ZFMK-MYR6121 & - & ZFMK \\
Kachincambala sp. & BuB1115 & - & PM \\
Kachincambala sp. & BuB4098 & - & PM \\
Electrocambalidae sp. & BuB1144 & - & PM \\
\hline
\end{tabular}

\section{Specimens and data deposition}

Specimens are from the private collection of Patrick Müller (Table 1). All type material were transferred to the collection of the ZFMK. Measurements of the amber pieces were made using a digital caliper.

All data generated is deposited in Morphobank (O’Leary \& Kaufmann 2011) under project number 3903 and can be accessed via the following link: http://morphobank.org/permalink/?P3903.

\section{Drawings}

Line drawings were made using a camera lucida mounted on a Olympus BX51 light microscope (Olympus Corporation, Tokyo, Japan), with 40-400 $\times$ magnification. Line drawings were transformed to ink on transparent paper, with PIGMA MICRON 04, 03 and 005 ink pens (Sakura, Hayward, USA). Line drawings were scanned and edited in Inkscape ver. 1.0.1.

\section{Photography}

Photographs of the studied specimens were made using a Canon EOS 7D camera mounted on a magnifier lens, to obtain images at different focus-levels. Image stacking was performed in Zerene Systems Stacker (ver. 1.04).

\section{Micro-CT and 3D-visualization}

For non-invasive 3D-visualization of the specimens, $\mu \mathrm{CT}$-scans were performed using a SKYSCAN 1272 (Brucker microCT, Kontich, Belgium) and the accompanying Control Software ver. 1.1.7 (Brucker microCT, Kontich, Belgium). All scans were performed with Flat Field Correction $=\mathrm{ON}$ and Geometrical Correction $=$ ON. Other scanning-parameters were adjusted to achieve optimal settings for each specimen. For scanning parameters see Morphobank. Reconstruction, ring-artefact reduction, misalignment compensation and beam-hardening correction were performed in NRecon ver. 1.7.0.4 (Brucker microCT, Kontich, Belgium). For one specimen (ZFMK-MYR7368) $\mu$ CT data were obtained in 2017 at the storage ring PETRA III (DESY, Hamburg, Germany) at Beamline P05 (Haibel et al. 2010; Greving et al. 2014; Wilde et al. 2016) operated by the Helmholzzentrum Geesthacht. Volume rendering and measurements were performed in Drishti ver. 2.6.3 (Limaye 2012). Gonopods of male specimens were segmented in ITK-Snap ver. 3.4.0 (Yushkevich et al. 2006) and rendered in Blender ver. 2.77. 


\section{Results}

\section{Class Diplopoda Gervais, 1844}

The specimens belong to the Diplopoda based on the following characters: diplosegments; gnathochilarium present.

\section{Subclass Helminthomorpha Pocock, 1887}

The specimens belong to the subclass Helminthomorpha based on the following characters: gonopods present; ozopores lateral; mandibular base divided.

\section{Superorder Juliformia Attems, 1926}

The specimens are identified as members of the superorder Juliformia based on the following characters: totally fused body rings; leg pairs 8 and 9 modified to gonopods; collum enlarged.

Order Spirostreptida Brandt, 1833

The specimens are identified as members of the extant order Spirostreptida based on the following character combination: architecture of anterior body rings, with a not completely fused $4^{\text {th }}$ body ring; body ring 4 seemingly legless; gnathochilarium with stipites not mesally fused and spanning along whole length of gnathochilarium.

Suborder Cambalidea Cook, 1895

The specimens are identified as members of the extant suborder Cambalidea based on the following character combination: anterior and posterior gonopod well-developed; gnathochilarium with eumentum and promentum.

Electrocambalidae fam. nov. urn:1sid:zoobank.org:act:C3EA19DA-7BED-407F-BD71-6C17D048E129

Figs $1-5$

\section{Type genus}

Electrocambala gen. nov.

\section{Diagnosis}

The new family Electrocambalidae fam. nov. differs from the suborder Spirostreptidea by the structure of the gnathochilarium, with a separate eumentum and promentum, as well as by the presence of two pairs of gonopods. Electrocambalidae fam. nov. differs from the cambalidean families Choctellidae and Pseudonannolenidae by the presence of well-developed posterior gonopods (Fig. 1B, G). The new family differs from the Choctellidae and Iulomorphidae by having distinctly arched metazonites from body ring 6 onwards, and long body rings with a length/diameter ratio $>0.7$ (Fig. 1B-C). Electrocambalidae fam. nov. differs from the Iulomorphidae by the presence of a relatively large first leg pair in the males (Figs 1D, 4E). The new family differs from the families Cambalidae, Cambalopsidae and Pseudonannolenidae (in which ozopores start from body ring 5 ) by the ozopores starting from body ring 6 (Figs 1B, 5C). Electrocambalidae fam. nov. differs from the Cambalidae and Cambalopsidae by the absence of tubercles 
on the metazonites. Electrocambalidae fam. nov. differs from other species of the order Spirostreptida in the combination of the following characters: (1) leg pair 3 moved anteriad, resulting in a seemingly legless body ring 3 in addition to the legless body ring 4 (Fig. 1B), (2) presence of setation on the posterior margin of the metazonites, and (3) pilosity on the head is not restricted to the labrum, but extends further up frontally on the head (Figs 1D, 3E, 5D).

\section{Etymology}

The family name is derived from the Latin word 'electrum' meaning 'amber' and the taxon Cambalidea, to which the studied fossils belong.

\section{Other genera included}

Kachincambala gen. nov.

Electrocambala gen. nov.

urn:lsid:zoobank.org:act:031BD521-9640-4628-8C00-81371D839F43

Figs $1-3$

\section{Type species}

Electrocambala ornata gen. et sp. nov.

\section{Diagnosis}

Electrocambala gen. nov. differs from Kachincambala gen. nov. by the presence of an accessory spine on the tarsus (Figs 1E, 3G). The anterior gonopod carries two rounded coxal lobes, the coxite is as long as the telopodite, and the outer lobe of the coxite is $1 / 3$ as long as the inner lobe. The apex of the posterior gonopod is curved anteriorly, creating an open channel (Fig. 1G-H).

\section{Etymology}

As for the family. Feminine.

\section{Other species included}

Electrocambala cretacea gen. et sp. nov.

Electrocambala ornata gen. et sp. nov. urn:1sid:zoobank.org:act:E66F551F-57A6-4FF6-BD95-C06FD4AD3627

Figs $1-2$

\section{Diagnosis}

Electrocambala ornata gen. et sp. nov. differs from Electrocambala cretacea gen. et sp. nov. by the presence of net-like ornamentation on the ventral half of the prozonite (Fig. 1F), V-shaped striae laterally on the collum (Fig. 1D) and the absence of longitudinal ridges on the body rings. Metazonite on ventral half with 7 longitudinal striae. Metazonite from body ring 4 onwards distinctly arched (Fig. 1A). Body rings 2-5 narrower than collum and following body rings (Fig. 1B). Anterior gonopod coxite more than twice as long as wide, with inner lobe longer than outer lobe, telopodite narrow, as long as coxite. Posterior gonopod simple, as long as anterior gonopod, projecting between inner and outer lobes of anterior gonopod (Fig. 1G-H). 


\section{Etymology}

From the Latin word 'ornatus' meaning 'ornamented' in reference to the net-like ornamentation and striae on the body rings of the species. Noun in apposition.

\section{Type material}

\section{Holotype}

MYANMAR • O ; Kachin State, Hukawng Valley, Mid-Cretaceous Burmese amber inclusion; formerly in the collection of Patrick Müller (BuB1151); ZFMK-MYR7369.

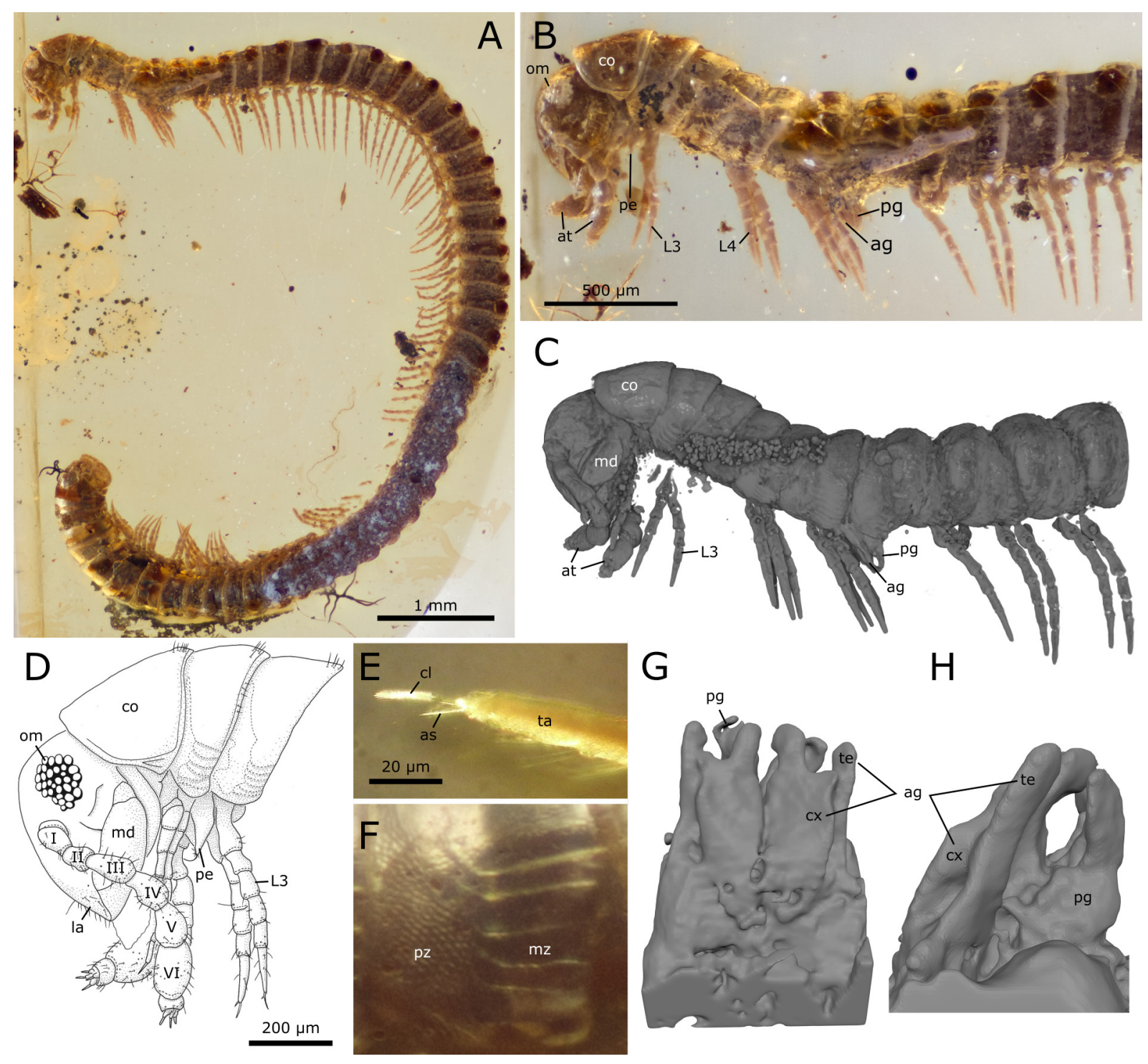

Fig. 1. Electrocambala ornata gen. et sp. nov., holotype, ổ (ZFMK-MYR7369). A. Habitus, lateral view, photograph. B. Head and anterior body rings, lateral view, photograph. C. Head and anterior body rings, lateral view, volume rendering. D. Head and anterior body rings, lateral view, drawing. E. Tarsus of midbody leg, photograph. F. Midbody ring, photograph. G. Gonopods, frontal view, segmentation. H. Gonopods, lateral view, segmentation. Abbreviations: ag = anterior gonopod; as = accessory spine; at = antennae; $\mathrm{cl}=$ claw co = collum; $\mathrm{cx}=$ coxite $\mathrm{L}=\mathrm{leg} ; \mathrm{la}=$ labrum; $\mathrm{md}=$ mandible; $\mathrm{mz}=$ metazonite; $\mathrm{om}=$ ommatidia; $\mathrm{pe}=$ penis; $\mathrm{pg}=$ posterior gonopod; $\mathrm{pz}=$ prozonite $; \mathrm{ta}=$ tarsus; te $=$ telopodite . 
Paratype

MYANMAR -1 ; ; same collection data as for holotype; formerly in the collection of Patrick Müller (BuB1142); ZFMK MYR7370.

\section{Other material examined}

MYANMAR • 1 ; ; same collection data as for holotype; in the collection of Patrick Müller (BuB1962) - 1 \%; same collection data as for holotype; in the collection of Patrick Müller (BuB1825).

\section{Description}

HABITUs. At least up to 46+6 (holotype, ZFMK-MYR7369) body rings (Fig. 1A) (ZFMK-MYR7370 = $42+3 ; \mathrm{BuB} 1825=40+4 ; \mathrm{BuB} 1962=45+4)$; body cylindrical, slender, up to at least $14.7 \mathrm{~mm}$ long, diameter $0.5 \mathrm{~mm}$, males smaller. Colour light to dark brown, posterior margin of metazonites light grey.

HEAD. As wide as collum and body ring 6 onwards, wider than body ring $2-5$ (Fig. 1B-C). Labrum and front of head with setae (Fig. 1D). 32/21 ommatidia (21 probably an artefact) arranged in circular patch. Incisura lateralis present, closed. Antennae reaching to posterior margin of body ring 4, with 7 antennomeres, covered by setae, $6>3>4=5>1>2>7$, with four apical sensory cones. Antennomeres 5 and 6 broader (Fig. 1D). Labrum tridentate. Mandible base divided into small cardo and large stipes (Fig. 1C-D). Gnathochilarium with eumentum and promentum, stipes along whole length of gnathochilarium, lamella lingualis not completely separated by promentum, not reaching to eumentum.

TRUnK. Collum only slightly curved, projecting over posterior margin of head (Fig. 1B-D). Collum with small triangular process projecting ventrally, reaching to height of upper margin of mandibular base, with 2 striae touching anterior forming a V (Fig. 1D). Body rings totally fused from body ring 5 onwards. Anterior four body rings with sternites free from pleuro-tergites. Prozonite separated from metazonite by constriction. Metazonite from body ring 6 onwards distinctly arched and wider than prozonite (Fig. 1C). Prozonite ventrally with net-like ornamentation (Fig. 1F). Metazonite ventrally with up to 7 longitudinal striae (Fig. 1F). Posterior margin of metazonites with 2-3 rows of setae (Fig. 1D). Ozopores from body ring 6 onwards lateral on metazonite, at middle height of body ring (Fig. 1B). Midbody rings (9) ca 0.7 times as long as diameter.

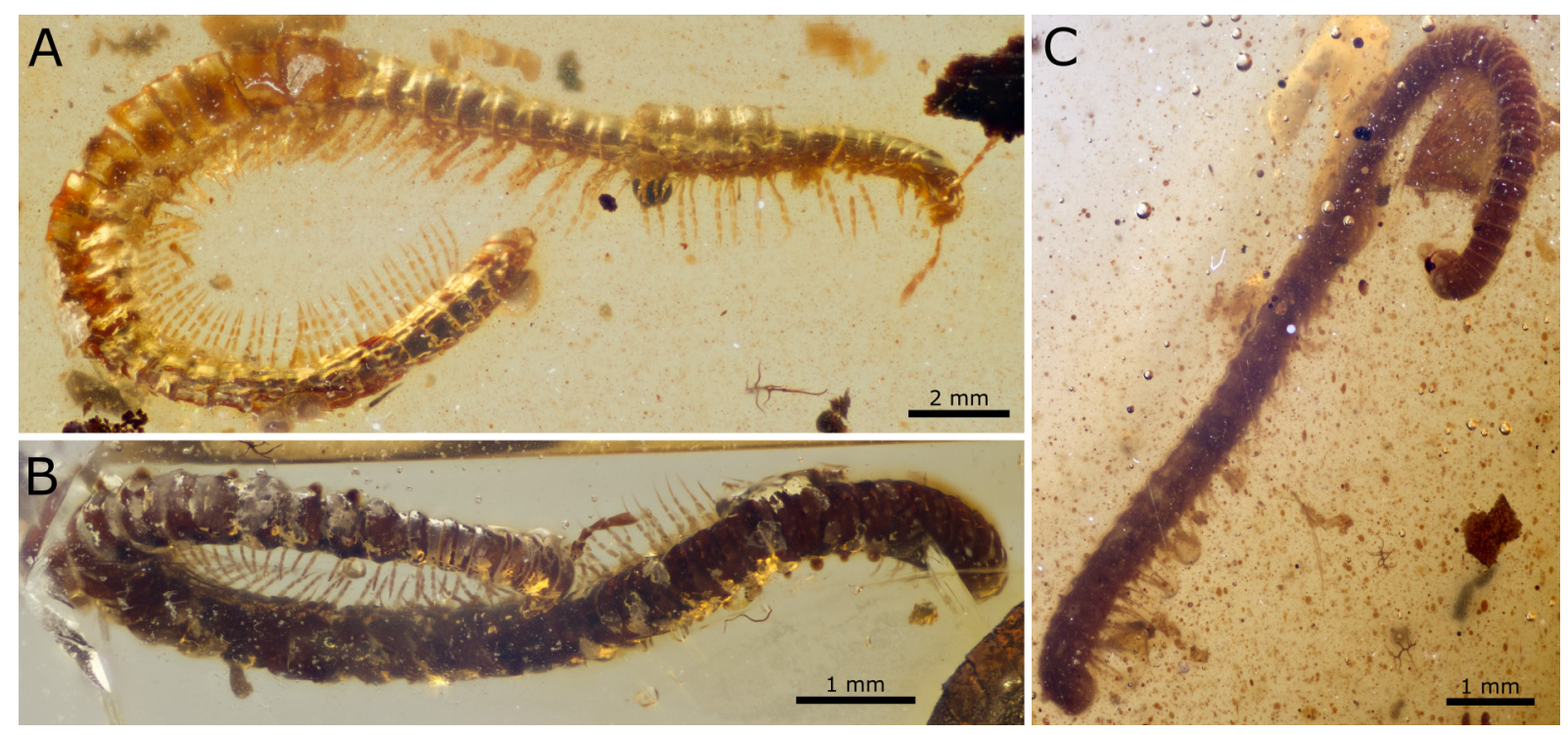

Fig. 2. Electrocambala ornata gen. et sp. nov., other material, photographs. A. § (BuB1962). B. $q$ (BuB1825). C. Paratype, o (ZFMK MYR7370). 
LEGS. First two leg pairs surrounded by first pleuro-tergite (collum), leg pair 3 surrounded by $2^{\text {nd }}$ pleurotergite close to $3^{\text {rd }}$ pleuro-tergite, body rings 3 and 4 seemingly legless, from body ring 5 onwards 2 leg pairs per body ring (Fig. 1B-C). Midbody legs with coxa, prefemur, femur, postfemur, tibia, tarsus. Tarsus $>$ prefemur $=$ femur $>$ postfemur $>$ tibia $>$ coxa. Podomeres with few setae. Tarsus with tarsal claw and accessory spine (Fig. 1E). Leg pairs 1 and 2 without accessory spine. Coxa of $2^{\text {nd }}$ leg pair inserts medial of coxa of $1^{\text {st }}$ leg pair.

POSTERIOR BODY RINGS. Preanal ring without epiproct projecting, with 5 longitudinal lateral grooves and setae. Anal valves with at least 10 marginal setae and up to 8 setae on surface. Subanal scale not projecting over anal valve. Posterior 3-6 body rings legless (Fig. 1A).

Male SeXual characters. Smaller and more slender than females (Figs 1A, 2A vs Fig. 2B-C). In male $1^{\text {st }}$ leg pair present, reduced in size not in segmentation, without tarsal claw. Penis with wide base and curved tip, with short setae (Fig. 1D). Anterior $\left(8^{\text {th }} \mathrm{leg}\right)$ and posterior gonopod $\left(9^{\text {th }} \mathrm{leg}\right)$ well-developed, on body ring 7 (Fig. 1B-C). Anterior gonopod coxite flat with two rounded apical lobes (inner and outer lobe), telopodite as long as inner coxal lobe, inserting at base of coxa, with few setae. Presence of flagellum unknown. Posterior gonopod as long as anterior gonopod, with rounded tip. Apex curved anteriorly, creating an open channel. Anterior surface with possible remnant of seminal groove reaching up to apex (Fig. 1G-H).

Female Sexual Characters. Larger and wider than male (Fig. 2B-C). First leg pair reduced in length and broadened. Vulva not sufficiently preserved for description.

\section{Remarks}

Electrocambala ornata gen. et sp. nov. was discovered in one case (ZFMK MYR7370) in the same amber stone as a specimen of Electrocambala cretacea gen. et sp. nov. described below, showing that both species lived in temporal and geographical sympatry, not unlike recent species of the Cambalopsidae in SE Asia (e.g., Likhitrakarn et al. 2020).

\section{Measurements and taphonomy}

\section{ZFMK-MYR7369}

AMBER DESCRIPTION. Amber flat, semi-circle, $15.45 \times 6.6 \times 2.84 \mathrm{~mm}$, polished, yellow, clear transparent.

SYNINCLUSIONS. Soil particles, stellate hairs, plant parts, Acari.

TAPHONOMIC FEATURES. Body curved as in defence (Fig. 1A). Defence fluid released from anterior body rings, form transparent dark brown bubbles above ozopores (Fig. 1B). Field of ommatidia damaged on left side. Gonopods everted (Fig. 1B). Anal-valves open (Fig. 1A). Body laterally slightly flattened. Body rings 26-38 damaged on right side and from leg pair 10 onwards right leg missing (artefact from polishing) (Fig. 1A).

\section{ZFMK-MYR7370}

MEASUREMENTS. $14.5 \mathrm{~mm}$ long, $0.5 \mathrm{~mm}$ in diameter.

AMBER DESCRIPTION. Amber flat, oval-shaped, $48.3 \times 29.5 \times 7.4 \mathrm{~mm}$, polished, yellow, reddish transparent.

Syninclusions. Soil particles, sporangia of fungi, bark, wood fibre, leaves, Diptera, Coleoptera, Electrocambala cretacea gen. et sp. nov., small brown droplets. 
TAPHONOMiC Features. Anterior body coiled as in defence (Fig. 2C). Field of ommatidia visible, but single ommatidia not distinguishable. Setation only partially preserved. Legs only partially preserved, mostly decayed (Fig. 2C). Vulva visible, but poorly preserved. Surrounded by brownish film.

\section{BuB1825}

MeASuREMENTS. $14.7 \mathrm{~mm}$ long, $0.5 \mathrm{~mm}$ in diameter.

AMBER DESCRIPTION. Amber flat, semi-circle, $18.23 \times 9.09 \times 4.05 \mathrm{~mm}$, polished, yellow to reddish, clear transparent, with fissures.

SYNINCLUSIONS. Sporangia of fungi, stellate hairs.

TAPHONOMIC FEATURES. Anterior body bent as in defence. Secretion of defence fluid (Fig. 2B). Setation not preserved. Legs only partially preserved (Fig. 2B). Characters partly obscured by body. Amber with fissure.

\section{BuB1962}

MEASUREMENTS. $11.9 \mathrm{~mm}$ long, $0.3 \mathrm{~mm}$ in diameter.

AMBER DESCRIPTION. Amber cuboid, $12.28 \times 5.57 \times 3.29 \mathrm{~mm}$, polished, yellow, clear transparent. From larger piece, includes 5 pieces.

SyninClusions. Soil particles, sporangia of fungi, stellate hairs, parts of arthropod appendages.

TAPHONOMIC FEATURES. Anterior body bent as in defence (Fig. 2A). Head damaged, antennae deformed, legs only partially preserved (Fig. 2A), anal valves of preanal ring missing, body rings 9-12 and 21-31 damaged.

Electrocambala cretacea gen. et sp. nov. urn:lsid:zoobank.org:act:83055E50-E37B-4253-8C8D-F14B0A749304

Fig. 3

\section{Diagnosis}

Electrocambala cretacea gen. et sp. nov. differs from Electrocambala ornata gen. et sp. nov. by the presence of at least two lateral ridges on the body rings (Fig. 3C), a prozonite without net-like ornamentation and a collum without lateral striae. Ommatidia arranged in rows (Fig. 3E). Male gonopods unknown.

\section{Etymology}

'Cretacea' in reference to the Cretaceous, the geological period to which the Burmese amber deposits are dated. Noun in apposition with a free ending.

\section{Type material}

\section{Holotype}

MYANMAR • 9 ; Kachin State, Hukawng Valley, Mid-Cretaceous Burmese amber inclusion; formerly in the collection of Patrick Müller (BuB1142); ZFMK-MYR7370.

\section{Description}

HABITUS. $55+3$ body rings; body cylindrical, slender, up to at least $17.9 \mathrm{~mm}$ long, $0.6 \mathrm{~mm}$ in diameter. Colour brown to greyish (Fig. 3B). 
HEAD. As wide as collum and body rings 6 onwards, wider than body rings 2-5 (Fig. 3C). Head and labrum with setae. 31/? ommatidia (left side obscured) arranged in 6 rows, posterior 4 rows with 6 ommatidia,
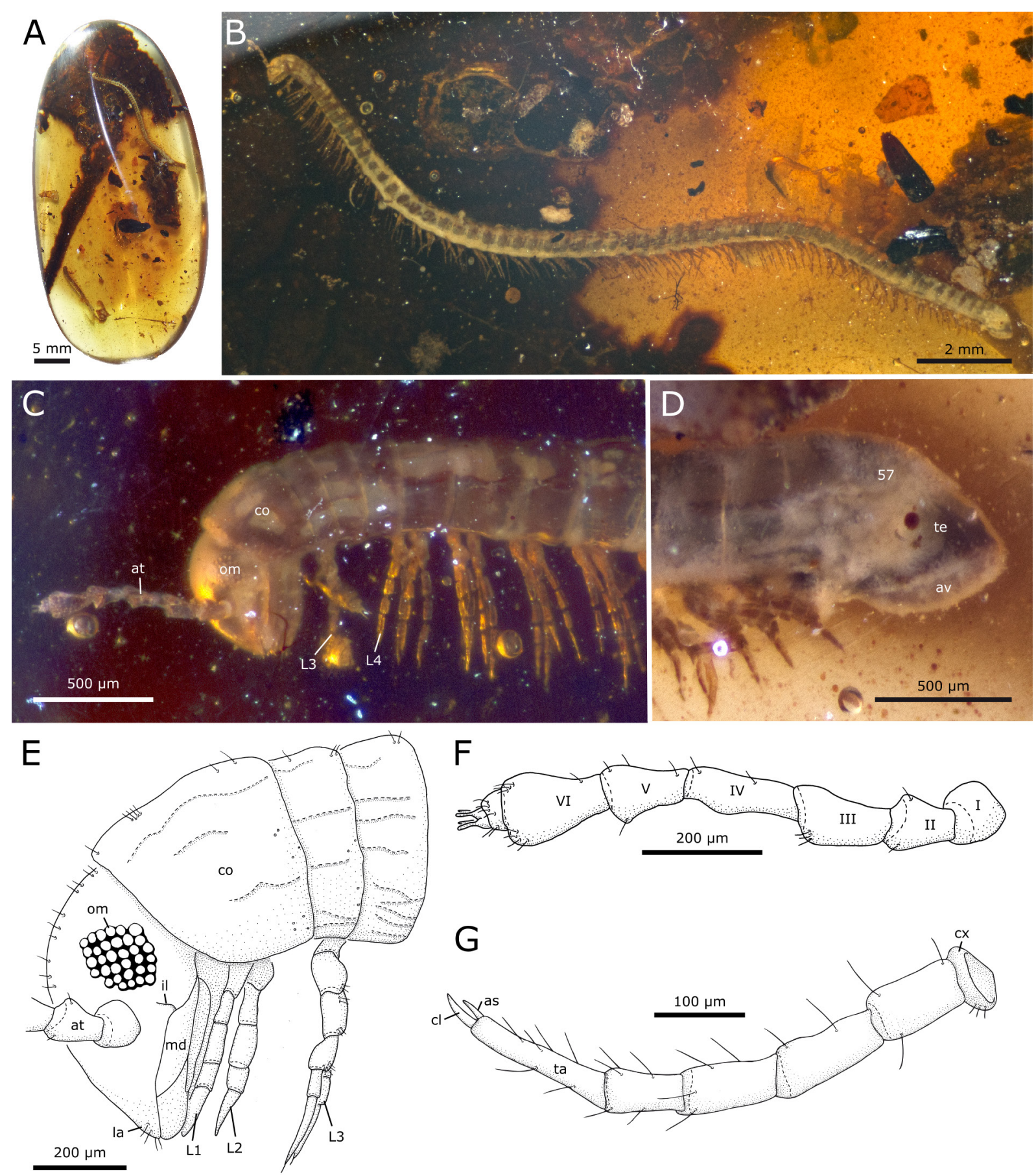

Fig. 3. Electrocambala cretacea gen. et sp. nov., holotype, $q$ (ZFMK-MYR7370). A. Amber piece, photograph. B. Habitus, lateral view, photograph. C. Head and anterior body rings, lateral view, photograph. D. Telson and posterior body rings, lateral view, photograph. E. Head and anterior body rings, lateral view, drawing. F. Antenna, drawing. G. Midbody leg, drawing. Abbreviations: $57=$ body ring 57; as = apical spine; at $=$ antennae; $\mathrm{av}=$ anal valve; $\mathrm{cl}=$ claw; $\mathrm{co}=$ collum; $\mathrm{cx}=\mathrm{coxa} ; \mathrm{il}=$ incisura lateralis; $\mathrm{L}=$ leg; la = labrum; $\mathrm{md}=$ mandible; $\mathrm{om}=$ ommatidia; $\mathrm{ta}=$ tarsus; te $=$ telson. 
row 5 (counted from posterior) with 5 , anterior row with 4 ommatidia. Incisura lateralis present, closed (Fig. 3E). Antennae reaching to body ring 5, with 7 antennomeres, covered by setae, $6=4>3>5>2>1>7$, with 4 sensory cones (Fig. 3F).

TRUNK. Collum slightly curved, covering posterior margin of head. Collum laterally without striae (Fig. 3C, F). Body rings totally fused from body ring 5 onwards, anterior four body rings with sternite free from pleuro-tergite. Metazonites from body ring 6 onwards distinctly arched and wider than prozonite (Fig. 3C). Body rings with several longitudinal ridges. Metazonites ventrally with at least 5 longitudinal striae, posterior margin with 1 or 2 rows of setae (Fig. 3E), ozopores start lateral from body ring 6 .

LEGs. Body ring 4 legless, from body ring 5 onwards 2 leg pairs per body ring. Midbody legs with coxa, prefemur, femur, postfemur, tibia, tarsus. Podomeres with few setae. Tarsus $>$ femur $>$ postfemur $=$ prefemur $>$ tibia $>$ coxa. Tarsus with tarsal claw and accessory spine (only visible on well preserved legs separated from body, other legs partly decomposed). Podomeres with setae (Fig. 3G). $1^{\text {st }}$ and $2^{\text {nd }}$ leg pair shorter and stouter than midbody legs (Fig. 3G).

POSTERIOR BODY RINGS. Preanal ring without epiproct projecting, with marginal setae. Subanal scale not projecting over anal valve. Posterior body rings and anal valves covered by fungi (Fig. 3D).

MALE. Unknown.

\section{Measurements and taphonomy}

MeASuREMENTs. $17.9 \mathrm{~mm}$ long, $0.6 \mathrm{~mm}$ in diameter.

AMBER DESCRIPTION. Amber flat, oval-shaped, polished, $48.3 \times 29.5 \times 7.4 \mathrm{~mm}$, yellow, reddish transparent (Fig. 3A).

Syninclusions. Same as in ZFMK-MYR7370 (Electrocambala ornata gen. et sp. nov.).

TAPHONOMIC FEATURES. From body ring 8 onwards body rings and anal valves partially covered by white, filamentous substance. Only right side of anterior body visible, left side obscured by leaf, several legs detached, next to body (Fig. 3B).

Electrocambala gen. nov. sp.

\section{Material examined}

MYANMAR • 1 ; Kachin State, Hukawng Valley, Mid-Cretaceous Burmese amber inclusion; in the collection of Patrick Müller (BuB1990).

\section{Measurements and taphonomy}

Measurements. $8.4 \mathrm{~mm}$ long, $0.5 \mathrm{~mm}$ in diameter.

Amber DeSCRIPTION. Semicircle, $15.5 \times 1.1 \times 2.6 \mathrm{~mm}$. Polished, yellow transparent.

SYNINCLUSIONS. Soil particles, sporangia of fungi, stellate hairs, small brown droplets.

TAPHONOMIC FEATURES. Specimen hollow, only sclerotized parts preserved. Only anterior 35 body rings preserved. From body ring 6 onwards only right half preserved. Cracks in amber filled by minerals. 


\section{Remarks}

This specimen is not sufficiently preserved to identify it as either one of the two species described above, or as a third species. This specimen was identified as a member of Electrocambala gen. nov. based on the following character combination: legs with accessory spine, gap between leg pair 3 and leg pair 4 .

Kachincambala gen. nov. urn:lsid:zoobank.org:act:D64F73BD-381E-4028-B362-EA1DE2B6442F

Figs $4-5$

\section{Type species}

Kachincambala muelleri gen. et sp. nov.

\section{Diagnosis}

Kachincambala gen. nov. differs from Electrocambala gen. nov. by the absence of an accessory spine on the tarsus (Fig. 5E) and in the structure of the gonopods (Fig. 4F-G).

\section{Etymology}

'Kachin', after the Myanmar state of Kachin where the amber deposits are located, and '-cambala', a common suffix for names in the Cambalidea. Feminine.

\section{Other species included}

Kachincambala distorta gen. et sp. nov.

Kachincambala muelleri gen. et sp. nov.

urn:1sid:zoobank.org:act:F9CC6697-1E02-4A41-AABA-1E5EE46D7AFA

Fig. 4

\section{Diagnosis}

Kachincambala muelleri gen. et sp. nov. differs from the only other species of the genus, $K$. distorta gen. et sp. nov., in gonopod characters. The anterior gonopod coxite is more stout in $K$. muelleri gen. et sp. nov., less than twice as long as wide, while it is more narrow in $K$. distorta gen. et sp. nov. The inner lobe is apically rounded, nearly triangular and bends mesally. The outer lobe of the anterior gonopod is short and broad, oriented more laterally than in K. distorta gen. et sp. nov. Telopodite of anterior gonopod is broad, shorter than coxite. Posterior gonopod simple, broad, reaching over inner lobe of coxite.

\section{Etymology}

In honour of Patrick Müller, who granted us access to his large collection of inclusions in Burmese amber for study, which resulted in the discovery of the specimens studied here, and who donated the type material to the ZFMK. Noun in the adjective case.

\section{Type material}

\section{Holotype}

MYANMAR • O ; Kachin State, Hukawng Valley, Mid-Cretaceous Burmese amber inclusion; formerly in the collection of Patrick Müller (BuB3757); ZFMK-MYR10225.

\section{Description}

HABitus. $>41$ body rings; cylindrical and slender, up to at least $12 \mathrm{~mm}$ long and $0.5 \mathrm{~mm}$ wide. Colour dark brown to greyish (Fig. 4A-C). 
HEAD. As wide as collum and body rings 6 onwards, wider than body rings $2-5$. Head and labrum with setae. Labrum with three teeth (Fig. 4D). $>30$ ommatidia arranged in several rows. Incisura lateralis present, closed. Antennae ca $800 \mu \mathrm{m}$ long, covered by setae, $7<1<2<4=5<3<6$, with four apical sensory cones (Fig. 4B). Mandible base with small cardo ca $1 / 4$ of length of large stipes (Fig. 4C). Gnathochilarium with mentum divided in eumentum and promentum, large triangular lamella lingualis, large stipites occupying entire length of gnathochilarium, with inner and outer palp (Fig. 4E).
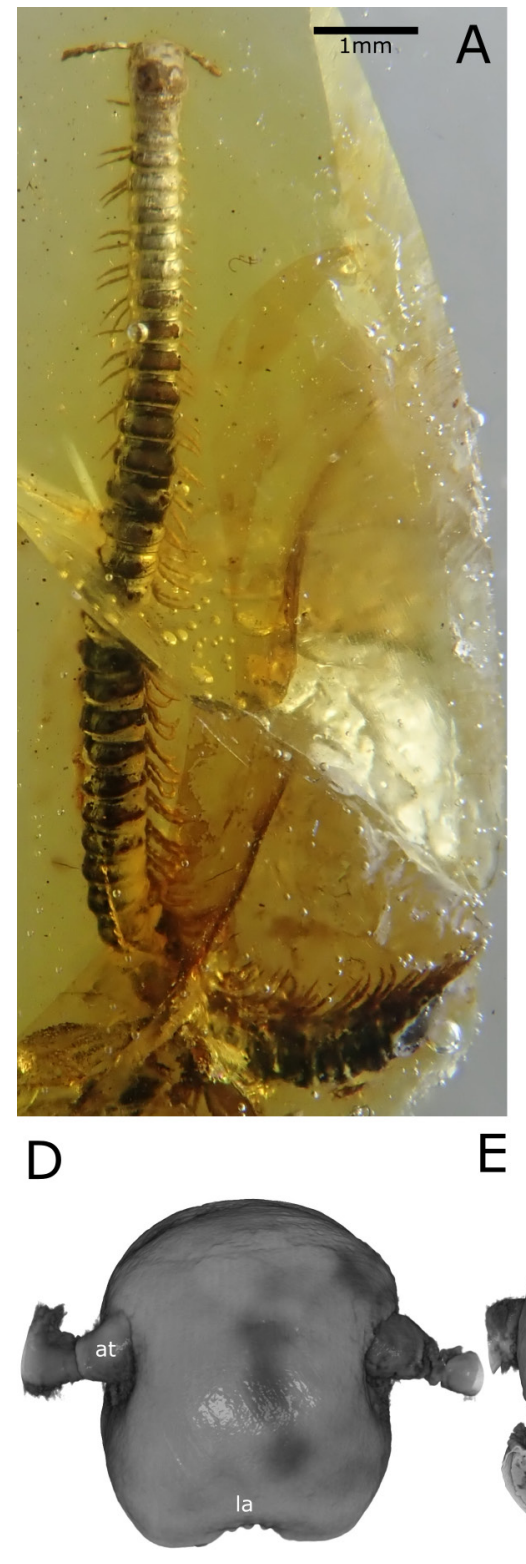

$\mathrm{E}$
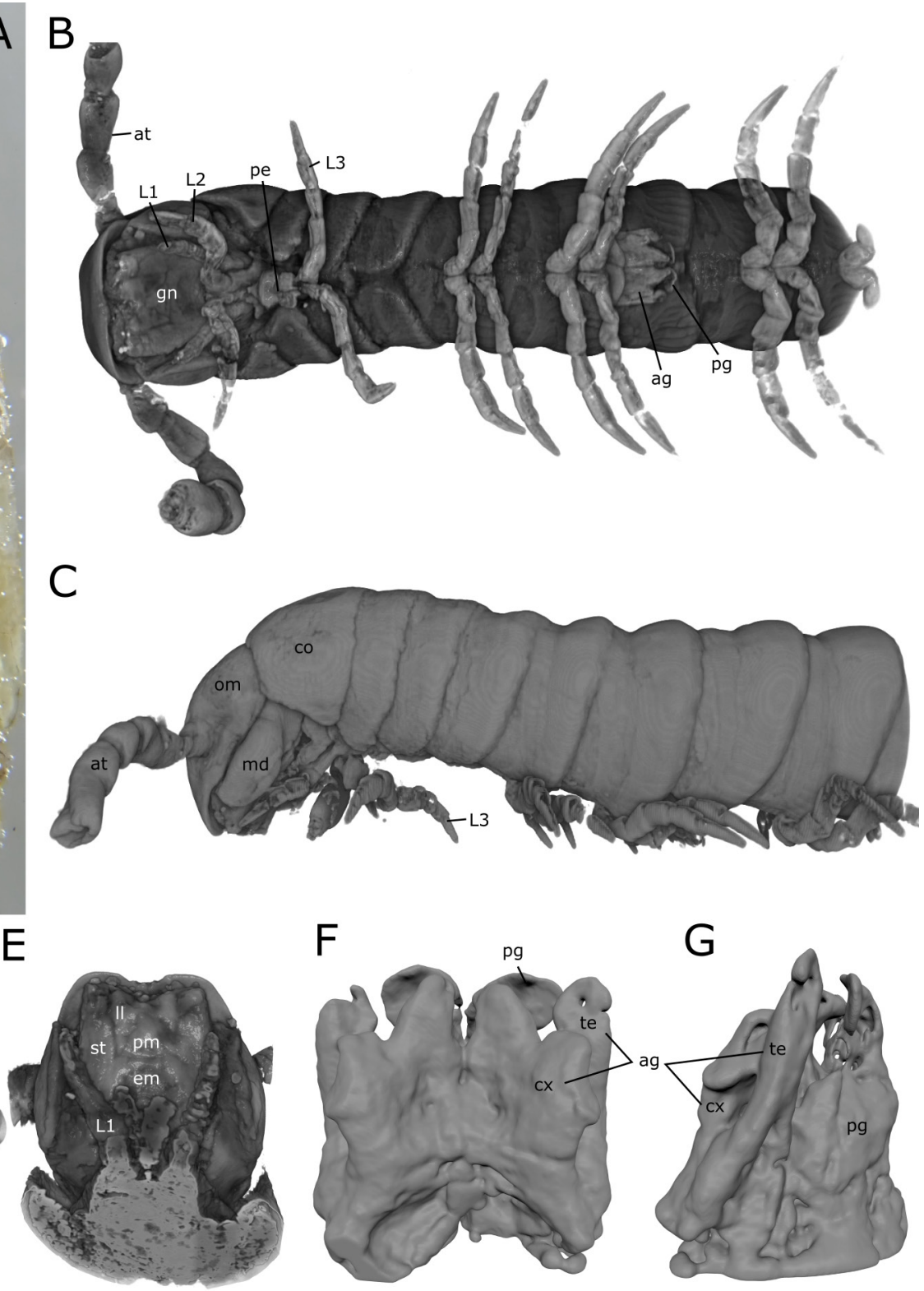

$\mathrm{F}$

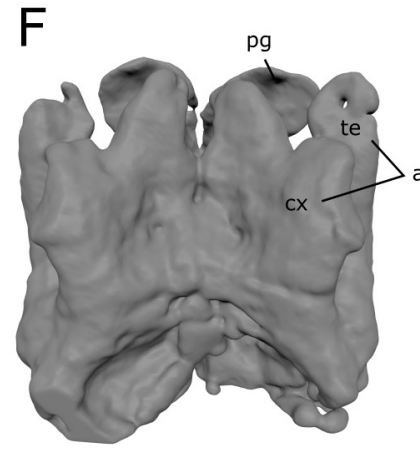

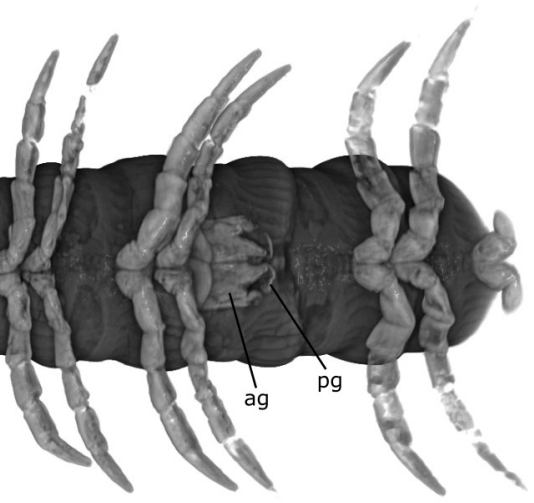

G

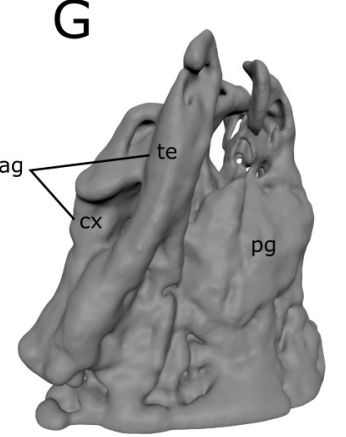

Fig. 4. Kachincambala muelleri gen. et sp. nov., holotype, ô (ZFMK-MYR10225). A. Habitus, dorsal view, photograph. B. Head and anterior body rings, ventral view, volume rendering. C. Head and anterior body rings, lateral view, volume rendering. D. head, frontal view, volume rendering. E. Head, ventral view, volume rendering. F. Gonopods, frontal view, segmentation. G. Gonopods, lateral view, segmentation. Abbreviations: ag = anterior gonopod; at $=$ antennae; $c 0=$ collum; $\mathrm{cx}=$ coxite; $\mathrm{em}=$ eumentum; $\mathrm{gn}=$ gnathochilarium; $\mathrm{L}=$ leg; la = labrum; 11 = lamella limgualis; $\mathrm{md}=$ mandible; $\mathrm{om}=$ ommatidia; $\mathrm{pe}=$ penis; $\mathrm{pg}=$ posterior gonopod; $\mathrm{pm}=$ promentum; $\mathrm{st}=$ gnathochilarial stipes; te $=$ telopodite . 
TRUNK. Collum large, laterally with triangular extension. Body rings 2-5 narrower than collum and following body rings. Body rings totally fused from body ring 5 onwards, anterior four body rings with sternite free from pleuro-tergite. Body rings from body ring 5 onwards with distinctly arched metazonite and wider than prozonite. Metazonite ventrally with 7-9 striae. Ozopores from body ring 6 onwards positioned ventro-lateral on metazonite (Fig. 4C).

LEGS. Body rings 3 and 4 seemingly legless, from body ring 5 onwards 2 leg pairs per body ring (Fig. 4B). Anterior three leg pairs shorter than following legs but not reduced in segmentation. Midbody legs with coxa, prefemur, femur, postfemur, tibia, tarsus. Podomeres covered by setae. Tarsus $>$ tibia $>$ prefemur $=$ femur $>$ postfemur $>$ coxa. Accessory spine on tarsus absent.

POSTERIOR BODY RINGS. Unknown.

MALE SEXUAL CHARACTERS. Leg pair 1 reduced in size, not in segmentation (Fig. 4A). Anterior gonopod plate-like, coxite with apically rounded inner lobe and shorter outer lobe, which extends laterad. Inner lobe ca two times as long as outer lobe. Telopodite as long as coxite's inner lobe, apically rounded. Presence of flagellum unknown. Posterior gonopod as long as anterior gonopod; apically with rounded lobe extending laterally (Fig. 4F-G).

FeMALE SEXUAL CHARACTERS. Unknown.

\section{Measurements and taphonomy}

MeAsurements. Ca $12 \mathrm{~mm}$ long, $0.5 \mathrm{~mm}$ in diameter.

AMBER DESCRIPTION. Flat, triangular, $15.5 \times 8.9 \times 3.0 \mathrm{~mm}$. Yellow transparent with brownish areas close to animal. With crack.

SYNINCLUSIONS. Insect remains, stellate hairs.

TAPHONOMIC FEATURES. Specimen straight. Posterior body rings missing (cut away). Mid body partially obscured by crack. Gonopods everted. Defence fluid released from ozopores (Fig. 4A).

Kachincambala distorta gen. et sp. nov. urn:lsid:zoobank.org:act:EBD66E4D-D2FB-40EC-B1EC-D429C7465428

Fig. 5

\section{Diagnosis}

Forty-two ommatidia arranged in circular patch (Fig. 5A). Anal valve with 8 marginal setae. Male leg pair 1 well-developed (Fig 5D). Kachincambala distorta gen. et sp. nov. differs from the only other species of the genus, $K$. muelleri gen. et sp. nov., in gonopod characters: unlike in $K$. distorta gen. et sp. nov., the posterior gonopod of $K$. muelleri gen. et sp. nov. does not possess a lateral lobe apically. On the anterior gonopod, the outer lobe of the anterior gonopod's coxite is nearly as long as the inner lobe in $K$ distorta gen. et sp. nov., while the outer lobe is short and broad, oriented more laterally in K. muelleri gen. et sp. nov. Furthermore, the anterior gonopod's telopodite is in $K$. distorta gen. et sp. nov. apically pointed and not rounded as in K. muelleri gen. et sp. nov. (Fig. 5F-G).

\section{Etymology}

From the Latin word 'distortus', meaning 'distorted' or 'deformed', referring to the strong deformation of the specimen and especially its gonopods. Noun in the adjective case. 


\section{Type material}

\section{Holotype}

MYANMAR • ${ }^{\lambda}$; Kachin State, Hukawng Valley, Mid-Cretaceous Burmese amber inclusion; formerly in the collection of Patrick Müller (BuB1839); ZFMK-MYR7368.
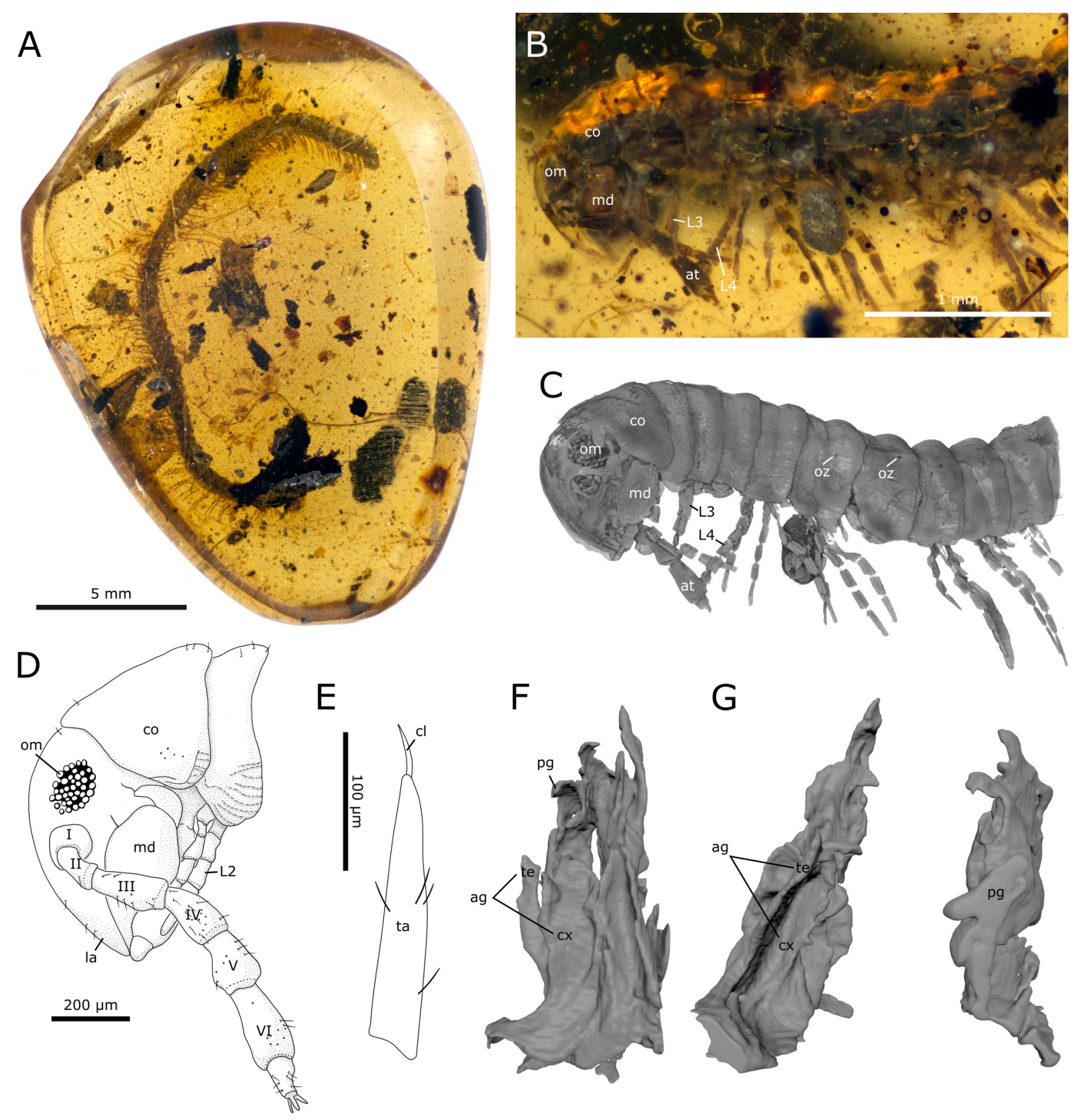

Fig. 5. Kachincambala distorta gen. et sp. nov., holotype, $\widehat{\partial}$ (ZFMK-MYR7368). A. Amber piece, photograph. B. Head and anterior body rings, lateral view, photograph. C. Head and anterior body rings, lateral view, volume rendering. D. Head, lateral view, drawing. E. Tarsus, drawing. F. Gonopods, anterior view, segmentation. G. Gonopods, lateral view, segmentation. Abbreviations: ag = anterior gonopod; at = antennae; $\mathrm{cl}=$ claw; $\mathrm{co}=$ collum; $\mathrm{cx}=$ coxite $\mathrm{L}=$ leg; $\mathrm{la}=$ labrum; $\mathrm{md}=$ mandible; om = ommatidia; $\mathrm{oz}=$ ozopore; $\mathrm{pg}=$ posterior gonopod; $\mathrm{ta}=$ tarsus; te $=$ telopodite. 


\section{Description}

HaBitus. $56+4$ body rings. Body cylindrical, slender, up to at least $20.8 \mathrm{~mm}$ in length, $0.4 \mathrm{~mm}$ in diameter. Colour grey to brown (Fig 5A).

HEAD. As wide as collum and body ring 6 onwards, wider than body rings 2-5. 42/39 ommatidia arranged in circular patch (Fig. 5C). Incisura lateralis present, closed. Antennae with 7 antennomeres, reaching to posterior margin of body ring $4,6=3>4>5>2>1>7$, with 4 apical sensory cones (Fig. 5D). Labrum tridentate, with setae. Mandibular base divided in small cardo and large stipes (Fig. 5D). Gnathochilarium with eumentum and promentum. Lamella lingualis reaching to lower third of promentum, not touching eumentum. Promentum not completely separating the lamellae lingualis. Stipes of gnathochilarium along whole length of gnathochilarium touching gula laterally.

TRUNK. Collum only slightly curved, projecting over posterior margin of head, reaching laterally to height of mandibular base (Fig. 5C). Collum ventrally with 6 grooves on posterior margin (Fig. 5D). Body rings totally fused from body ring 5 onwards. Metazonite from body ring 5 onwards distinctly arched, wider than prozonite. Metazonite ventrally with 6 to 9 striae (Fig. 5C). Posterior margin dorsally with few setae (Fig. 5D). Ozopores start on body ring 6. Midbody rings (9) ca 0.8 times as long as diameter (Fig. 5C).

LEGS. First two leg pairs surrounded by first pleuro-tergite (collum), leg pair 3 surrounded by $2^{\text {nd }}$ pleurotergite, body rings 3 and 4 legless, from body ring 5 onwards 2 leg pairs per body ring (Fig. 5C). Midbody legs with coxa, prefemur, femur, postfemur, tibia, tarsus. Podomeres with few setae. Tarsus with one claw, no apical spine (Fig. 5E). Tarsus $>$ prefemur $>$ postfemur $>$ femur $=$ tibia $>$ coxa. Coxa of $2^{\text {nd }}$ leg pair inserted medial of coxa of $1^{\text {st }}$ leg pair.

PoSTERIOR BODY RINGS. Preanal ring without epiproct projecting, with few setae. Valves with at least 8 marginal setae. Subanal scale not projecting over valve.

MALE SEXUAL CHARACTERS. In males leg pairs 1 and 2 slightly reduced in size but not in segmentation. In leg pair 2 femur $>$ tarsus $>$ tibia $=$ postfemur $=$ prefemur $>$ coxa. Except leg pair 1 with tarsal claw. Coxa of leg pair 2 inserted medial of coxa of leg pair 1. Paired penis located behind leg pair 2, within pouch. Anterior and posterior gonopods on body ring 7 well-developed, retracted into body. Left gonopods highly deformed (Fig. 5F-G). Anterior gonopod with telopodite slightly longer than coxite, apically pointed. Coxite long, slender, with two lobes, outer lobe pointed and nearly as long as inner lobe. Inner lobe apically rounded. Presence of flagellum unknown. Posterior gonopod longer than anterior gonopod, anterior surface of posterior gonopod with possible seminal groove (Fig. 5F-G).

\section{Measurements and taphonomy}

Measurements. $20.8 \mathrm{~mm}$ long, $0.4 \mathrm{~mm}$ in diameter (Fig. 5A).

AMBER DeSCRIPTION. Amber flat, elliptical, $19.7 \times 14.8 \times 3.9$ mm. Polished, yellow transparent (Fig. 5A).

SyNinCLUSIONS. Soil particles, plant parts, pollen, antennae, leg parts and cuticle of arthropods.

TAPHONOMIC FEATURES. Specimen bend dorsally. Front of specimen laterally flattened (compressed, cuticle partially broken) (Fig. 5A). Left antenna missing (Fig. 5B). Preanal segment damaged. 
Kachincambala gen. nov. sp.

\section{Material examined}

MYANMAR • 1 specimen; Kachin State, Hukawng Valley, Mid-Cretaceous Burmese amber inclusion; in the collection of Patrick Müller (BuB1115).

\section{Measurements and taphonomy}

MeASurements. $9.0 \mathrm{~mm}$ long, $0.3 \mathrm{~mm}$ in diameter.

Amber DeSCRiPtion. Rectangular, $14.2 \times 5.3 \times 2.5 \mathrm{~mm}$. Polished, yellow, transparent.

SYNINCLUSIONS. Sporangia of fungi, pollen grains, plant parts.

TAPHONOMIC FEATURES. Laterally flattened. Head damaged on both sides, body rings partially damaged on left side. Muscles visible within legs. Amber with fissure along specimen.

\section{Remarks}

This specimen is identified as a member of Kachincambala gen. nov. based on the absence of an accessory spine. The poor preservation of this specimen prevents any assignment to the species of Kachincambala described here or to describe it as a new species.

Kachincambala gen. nov. sp.

\section{Material examined}

MYANMAR • 1 đ; Kachin State, Hukawng Valley, Mid-Cretaceous Burmese amber inclusion; ZFMKMYR6121.

\section{Measurements and taphonomy}

MeASUREMENTS. $5.3 \mathrm{~mm}$ long, $0.3 \mathrm{~mm}$ in diameter, $24+6$ body rings.

AMBER DESCRIPTION. Oval, flat, $6.0 \times 13.5 \times 4.1 \mathrm{~mm}$. Light yellow, transparent.

SyninClusions. Archaeognatha, aphid, Hymenoptera?, mite, stellate hair.

TAPHONOMIC FEATURES. Anterior body rings compressed. Posterior body rings partly polished away.

\section{Remarks}

This specimen is identified as a member of the Electrocambalidae fam. nov. based on the large gap between leg pairs 3 and 4 and the presence of setae on the head and the posterior margin of the body rings. It is determined as a member of Kachincambala gen. nov. based on the absence of an accessory spine. For a detailed description the animal is not sufficiently preserved.

Kachincambala gen. nov. sp.

\section{Material examined}

MYANMAR • 1 q; Kachin State, Hukawng Valley, Mid-Cretaceous Burmese amber inclusion; in the collection of Patrick Müller (BuB4098). 


\section{Measurements and taphonomy}

Measurements. $13.0 \mathrm{~mm}$ long, $0.4 \mathrm{~mm}$ in diameter, $43+3$ body rings.

AMBER DESCRIPTION. Triangular, flat, $15.0 \times 10.8 \times 2.3 \mathrm{~mm}$. Light yellow, transparent.

SYNINCLUSIONS. Stellate hairs.

TAPHONOMIC FEATURES. Anterior body rings compressed. Posterior body rings partly polished away.

Electrocambalidae fam. nov. sp.

\section{Material examined}

MYANMAR • 1 specimen; Kachin State, Hukawng Valley, Mid-Cretaceous Burmese amber inclusion; in the collection of Patrick Müller (BuB1144).

\section{Measurements and taphonomy}

MeAsurements. $13.8 \mathrm{~mm}$ long, $0.4 \mathrm{~mm}$ in diameter.

Amber DESCRIPTION. Spherical, flat, $44.4 \times 33.6 \times 15.9$ mm. Polished, yellow, transparent.

Syninclusions. Soil particles, bark, Archaeognatha, Diptera, Hymenoptera (wasp, ant).

TAPHONOMIC FEATURES. Body straight. Imprint of body next to specimen. Body dorsally flattened, cuticle partially broken. Layering of amber.

\section{Discussion}

\section{Characters of the Electrocambalidae fam. nov.}

The family Electrocambalidae fam. nov. is distinct from all Cambalidea and Spirostreptidea by the position of leg pair 3. Leg pair 1 and 2 both appear to be situated on the collum and leg pairs 3 is shifted to body ring 2 in the Electrocambalidae fam. nov., resulting in an apparently legless third body ring, in addition to the seemingly legless fourth body ring observable in all Spirostreptida. This shift of leg pair 3 is the strongest argument in support of the new family, since it also requires modifications of the muscular and tracheal system, associated to the sternites, carrying the legs.

Electrocambalidae fam. nov. shares with the remaining Spirostreptida the architecture of the anterior body rings. In the Electrocambalidae fam. nov. the pleuro-tergites and sternites of body rings 2 to 4 are not completely fused; thus, the sternites carrying the first three leg pairs are free and separated from the pleuro-tergites. Among the Juliformia (Julida, Spirostreptida, Spirobolida), a free leg pair 3 in combination with four not fully fused body rings is only present in the order Spirostreptida, as pointed out by Verhoeff (1928-1932) and Mauriès (1992). In the Julida and the Spirobolida only the anterior three body rings are not totally fused while from body ring 4, which carries a single pair of legs (the third pair in Julida, the fourth pair in Spirobolida), and onwards, the pleuro-tergites and sternites are totally fused (Verhoeff 1928-1932; Mauriès 1992). The Julida have a maximum of only two free leg pairs, while the Spirobolida show a special case within the Juliformia, with three free leg pairs, despite having only three not fully fused body rings (Verhoeff 1928-1932). Because of the differences in the trunk-ring architecture, Hoffman (1982) did not accept a monophyletic superorder Juliformia but placed the Spirobolida in its own superorder Anocheta Cook, 1895, and the Julida and the Spirostreptida together with the Siphoniulida in the Diplocheta Cook, 1895, a placement not recovered in any phylogenetic analyses (e.g., Sierwald et al. 2003; Blanke \& Wesener 2014). 
Electrocambalidae fam. nov. shares with the Julida the metazonital setation of the body rings. Metazonital setation is common in species of the order Julida, which usually bear a single row of setae (Enghoff 1981). In the Spirobolida setation of the body rings is only known from the Typhlobolellidae Hoffman, 1969, a troglobitic family (Enghoff et al. 2015). Setae on the margin of the metazonites are characters usually not found in species of the order Spirostreptida (Enghoff et al. 2015). The only exceptions can be found in the Cambalidean genera Hypocambala Silvestri, 1897, of the family Cambalopsidae, and Jamilka Shear, 1973, of the family Cambalidae, which bear single a row of setae or are densely covered by setae on the body rings (Jeekel 1963; Enghoff 1981, Jiang et al. 2021). Enghoff (1981) suggested that the metazonital setation in the Julida is a plesiomorphic character, as could also be the case in the here proposed Electrocambalidae fam. nov. Furthermore, in the Electrocambalidae fam. nov. setation of the head is present on the labrum and extends up to the anterior margin of the collum. Within Spirostreptida a similar setation pattern of the head can only be observed in a few species of the genus Hypocambala (Jiang et al. 2021).

The following characters of the Electrocambalidae fam. nov. are shared with the Cambalidea: (1) the structure of the gnathochilarium, (2) the structure of the gonopods, and (3) developmental characters (euanamorphosis, as indicated by the presence of apodous body rings in front of the telson in mature specimens).

(1) The gnathochilarium of the Electrocambalidae fam. nov. corresponds to the state found in several cambalidean families and differs markedly from the structure found in the Julida and Spirobolida. The gnathochilarium of the Electrocambalidae fam. nov. consists of the lateral stipites, which reach over the full length of the gnathochilarium. A basal eumentum and an anterior, triangular promentum are present at its centre. Although the structure of the gnathochilarium is highly variable within the families of the Cambalidea, the structure seen in the Electrocambalidae fam. nov. can be found in representatives within all cambalidean families (e.g., Schubart 1966 for Iulomorpha Porat, 1872; Loomis 1938 for Tridere Loomis, 1938; Mauriès1983, 1987 for Podoglyphiulus Attems, 1909 and Pseudonannolene Silvestri, 1895). In contrast to the Cambalidea the structure of the gnathochilarium is highly conserved in the suborder Spirostreptidea (Jeekel 1985) and the order Spirobolida (Enghoff et al. 2015), which both have an undivided duplomentum, as well as in the order Julida, which has the mentum and the stipites fused (with the exception of Parajulidae Bollman, 1893 (Jeekel 1985)) and differs clearly from the state in the fossil family.

(2) In the Electrocambalidae fam. nov. the $8^{\text {th }}$ and $9^{\text {th }}$ leg pairs on body ring 7 are both modified to well-developed gonopods. Within the order Spirostreptida this character state can only be found in the suborder Cambalidea, as classified by Hoffman (1980, 1982), consisting of the families Cambalidae, Cambalopsidae and Iulomorphidae. In the Spirostreptidea, Choctellidae and Pseudonannolenidae the $8^{\text {th }}$ leg pair is modified, and the $9^{\text {th }}$ reduced or absent (Hoffman 1982; Enghoff et al. 2015). Furthermore, the Electrocambalidae fam. nov. seem to be opisthospermophorous or amphispermophorous with the posterior gonopod, which possibly shows the remnants of a seminal groove, being involved in sperm transfer. In the orders Julida and Spirobolida, and the families Cambalopsidae and Cambalidae, the posterior gonopod is the functional gonopod (= opisthospermophory) and the anterior gonopod serves as claspers or rarely assists in sperm transfer (= amphispermophorous) (Jeekel 1985 for Cambalidae and Cambalopsidae; Enghoff et al. 2015 for Spirobolida and Julida). The Iulomorphidae are amphispermophorous with a tendency towards protospermophory (Jeekel 1985). The families Pseudonannolenidae and Choctellidae, and the suborder Spirostreptidea, which lack a fully developed posterior gonopod, are protospermophorous (Jeekel 1985). Therefore, the ancestral state in the Juliformia is most likely opisthospermophory, with a functional posterior gonopod and an accessory anterior gonopod, as seen in our Electrocambalidae fam. nov., and the shift of the sperm transfer function to the anterior gonopod occurred in the suborder Spirostreptidea, and the families Choctellidae and Pseudonannolenidae. 
MORITZ L. \& WESENER T., Electrocambalidae, a new millipede family from Cretaceous amber

(3) While most species of the suborder Spirostreptidea are hemianamorphic, with body rings only added to a certain stadium, and further moults taking place without an addition of body rings (Enghoff et al. 1993), in Cambalidea adults show apodous body rings in front of the telson, suggesting euanamorphosis. Body rings are added with every moult until the death of the animal (Enghoff et al. 1993). We suggest that the Electrocambalidae fam. nov. are euanamorphic as well, because males show completely developed gonopods and apodous body rings at the same time. This means that after reaching sexual maturity body rings are still added.

Other characters of the Electrocambalidae fam. nov. are (1) ozopores starting from body ring 6 and (2) a relatively well-developed first leg pair in males. The position of the first ozopores (1) varies within the Juliformia, with few exceptions, between body rings 5 and 6 (Attems 1926; Verhoeff 1928-1932; Enghoff 2015). In the cambalidean families Cambalidae (Reboleira et al. 2015), Cambalopsidae (Korsós \& Johns 2009), and Pseudonannolenidae (Iniesta \& Ferreira 2013a, 2013b) ozopores start on body ring 5, while ozopores start on body ring 6 in Choctellidae (Chamberlin 1918) and Iulomorphidae (Verhoeff 1924; Korsós \& Johns 2009), as is the case in the Electrocambalidae fam. nov. A well-developed first leg pair in males (2) can be found in several spirostreptidan taxa (see above). In the studied male specimens the first leg pair was only slightly reduced in size but not in segmentation. Golovatch et al. (2007) stated that the cambalopsid species Glyphiulus costulifer Golovatch, Geoffroy, Mauriès \& VandenSpiegel, 2007 is probably the most basal representative of the genus because of the nearly unmodified first male legs (Golovatch et al. 2007), while Enghoff (1981) regarded the presence of unmodified first legs in Julida as reversals. Therefore, it is not clear whether or not the presence of an unmodified first leg pair in the fossil specimens is a plesiomorphic condition. At the moment the relationship of the Electrocambalidae fam. nov. to the remaining Spirostreptida and Juliformia remains speculative. To clarify the phylogenetic position of the Electrocambalidae fam. nov. a phylogenetic reconstruction including a broad sampling of juliformian taxa is needed.

The fossils were found in the present distributional range of the family Cambalopsidae, which are endemic to South-East Asia (Jeekel 1985; Shelley \& Golovatch 2011). This does not necessarily indicate a closer relationship between the new family and the Cambalopsidae, as data on the Mesozoic distribution of the Spirostreptida is lacking.

\section{The fossil record of the Spirostreptida}

The here described Electrocambalidae fam. nov. are the oldest known fossils of the order Spirostreptida. Thus, there are no other Spirostreptida fossils known from the Mesozoic, and the only known fossils of the order are Protosilvestria sculpta Handschin, 1944 (Cambalidae or Cambalopsidae) from the Oligocene (ca 23.03-33.0 ma) of France (Handschin 1944; Mauriès 1992) and the undescribed pseudonannolenid Epinannolene sp., from 20 my old Dominican amber (Santiago-Blay \& Poinar 1992). Twelve specimens, four species, two genera and one family are here added to the fossil record of the Spirostreptida, all from Burmese amber dating back to the Cretaceous, ca 99 ma (Shi et al. 2012). These fossils are ca 70 my older than the previously oldest known Spirostreptida and narrow the gap between the estimated appearance of the order Spirostreptida and suborder Cambalidea ca 514 ma (Shelley \& Golovatch 2011). The fossil record of the Juliformia, as for the Diplopoda in general, remains scarce and fragmentary, but the exceptional preservation of millipedes in Burmese amber offers the opportunity to greatly enlarge the fossil record. In the same way representatives of the other diplopod orders can be expected to be found in Burmese amber and widen our understanding of the evolution of the Diplopoda tremendously.

\section{Acknowledgements}

We thank Patrick Müller for granting us access to his collection of Burmese amber inclusions and for the donation of several specimen to the ZFMK collection. Thorsten Klug is thanked for his assistance 
and the acquisition of photographs. Peter Rühr (University of Bonn) and Jörg U. Hammel (HelmholtzZentrum-Geesthacht) are thanked for SR- $\mu$ CT data on ZFMK-MYR7368. Henrik Enghoff (Natural History Museum of Denmark) is thanked for discussions. We thank two anonymous reviewers for their comments, which greatly helped to improve the quality of the manuscript. The data presented in this publication are part of the Master thesis of LM in the M.Sc. program Organismic Biology, Evolutionary Biology and Paleobiology (OEP-Biology) at the University in Bonn and was conducted at the ZFMK under the supervision of TW. LM is thankful to Prof. Jes Rust (University of Bonn) for the evaluation of this Master thesis and for encouragement. LM is funded in the scope of the DFG-project "Phylogeny of the Diplopoda: micro-CT scans, morphology and morphometry of all millipede orders" (DFG WE 2479/4-1 and BL 1355/5-1) by Prof. Dr A. Blanke (University of Bonn) and TW.

\section{References}

Attems C. 1900. Dr. Brauer's Myriopoden-Ausbeute auf den Seychellen im Jahre 1895. Zoologische Jahrbücher, Abteilung für Systematik, Geographie und Biologie der Thiere 13: 133-171.

Attems C. 1926. Progoneata. In: Krumbach T. (ed.) Handbuch der Zoologie. Vol. IV. Part 1. Progoneata. Chilopoda. Insecta 1: 7-238. Walter de Gruyter, Berlin.

Blanke A. \& Wesener T. 2014. Revival of forgotten characters and modern imaging techniques help to produce a robust phylogeny of the Diplopoda (Arthropoda, Myriapoda). Arthropod Structure \& Development 43 (1): 63-75. http://doi.org/10.1016/j.asd.2013.10.003

Brewer M.S., Sierwald P. \& Bond J.E. 2012. Millipede taxonomy after 250 years. Classification and taxonomic practices in a mega-diverse yet understudied arthropod group. PloS One 7 (5): 1-12. http://doi.org/10.1371/journal.pone.0037240

Cárcamo H.A., Abe T.A., Prescott C.E., Holl F.B. \& Chanway C.P. 2000. Influence of millipedes on litter decomposition, $\mathrm{N}$ mineralization, and microbial communities in a coastal forest in British Columbia, Canada. Canadian Journal of Forest Research 30 (5): 817-826. https://doi.org/10.1139/x00-014

Chamberlin R.V. 1918. Myriapods from Nashville, Tennessee. Psyche 25 (2): 23-30. https://doi.org/10.1155/1918/65230

Crawford C.S. 1992. Millipedes as model detritivores. Berichte des Naturwissenschaftlich-Medizinischen Vereins in Innsbruck 10: 277-288.

Crossley D.A. 1977. The roles of terrestrial saprophagous arthropods in forest soils. Current status of concepts. In: Mattson W.J. (ed.) The Role of Arthropods in Forest Ecosystems: 49-56. Springer, Berlin. https://doi.org/10.1007/978-3-642-88448-1_6

Cruickshank R.D. \& Ko K. 2003. Geology of an amber locality in the Hukawng Valley, northern Myanmar. Journal of Asian Earth Sciences 21 (5): 441-455. https://doi.org/10.1016/S1367-9120(02)00044-5

Duy-Jacquemin M.N. \& Azar D. 2004. The oldest records of Polyxenida (Myriapoda, Diplopoda). New discoveries from the Cretaceous ambers of Lebanon and France. Geodiversitas 26 (4): 631-641.

Dzik J. 1975. Spiroboloid millipeds from the Late Cretaceous of the Gobi Desert, Mongolia. Paleontologia Polonica 33: 17-24.

Dzik J. 1981. An early Triassic millipede from Siberia and its evolutionary significance. Neues Jahrbuch für Geologie und Paläontologie - Monatshefte 7: 395-404. http://doi.org/10.1127/njgpm/1981/1981/395

Edgecombe G.D. 2015. Diplopoda - fossils. In: Minelli A. (ed.) Treatise on Zoology-Anatomy, Taxonomy, Biology. The Myriapoda, Volume 2: 337-351. Brill, Leiden. https://doi.org/10.1163/9789004188273_015

Enghoff H. 1981. A cladistic analysis and classification of the millipede order Julida. Journal of Zoological Systematics and Evolutionary Research 19: 285-319. 
MORITZ L. \& WESENER T., Electrocambalidae, a new millipede family from Cretaceous amber

Enghoff H. 1984. Phylogeny of millipedes - a cladistic analysis. Journal of Zoological Systematics and Evolutionary Research 22 (1): 8-26. https://doi.org/10.1111/j.1439-0469.1984.tb00559.x

Enghoff H., Dohle W. \& Blower J.D. 1993. Anamorphosis in millipedes (Diplopoda) - the present state of knowledge with some developmental and phylogenetic considerations. Zoological Journal of the Linnean Society 109 (2): 103-234. https://doi.org/10.1111/j.1096-3642.1993.tb00305.x

Enghoff H., Golovatch S., Short M., Stoev P. \& Wesener T. 2015. Diplopoda - taxonomic overview. In: Minelli A. (ed.) Treatise on Zoology - Anatomy, Taxonomy, Biology. The Myriapoda, Volume 2: 363-453. Brill, Leiden. https://doi.org/10.1163/9789004188273_017

Fritsch A. 1910. Miscellanea Palaeontologica - II. Mesozoica. Selbstverlag, Prag. Available from https://www.biodiversitylibrary.org/page/50493897 [accessed 6 Jun. 2021].

Gervais P. 1844. Études sur les myriapodes et les insects. Recherches zoologiques: 1-531.

Golovatch S.I., Geoffroy J.J., Mauries J. \& Van den Spiegel D. 2007. Review of the millipede genus Glyphiulus Gervais, 1847, with descriptions of new species from Southeast Asia (Diplopoda, Spirostreptida, Cambalopsidae). Part 1. The granulatus-group. Zoosystema 29 (1): 7-49.

Greving I., Wilde F., Ogurreck M., Herzen J., Hammel J.U., Hipp A., Friedrich F., Lottermoser L., Dose T., Burmester H., Müller M. \& Beckmann F. 2014. P05 imaging beamline at PETRA III: first results. Proceedings of SPIE 9212 - Developments in X-Ray Tomography IX: 921200.

https://doi.org/10.1117/12.2061768

Grimaldi D., Engel M.S. \& Nascimbene P.C. 2002. Fossiliferous Cretaceous amber from Myanmar (Burma). Its rediscovery, biotic diversity, and paleontological significance. American Museum Novitates 3361: 1-72. https://doi.org/10.1206/0003-0082(2002)361<0001:FCAFMB >2.0.CO;2

Haibel A., Ogurreck M., Beckmann F., Dose T., Wilde F., Herzen J., Müller M., Schreyer A., Nazmov V., Simon M., Last A. \& Mohr J. 2010. Micro- and nano-tomography at the GKSS Imaging Beamline at PETRA III. Proceedings of SPIE 7804 - Developments in X-Ray Tomography VII: 78040B. https://doi.org/10.1117/12.860852

Handschin E. 1944. Insekten aus den Phosphoriten des Quercy. Schweizerische palaeontologische Abhandlungen 64 (4): 1-23.

Hoffman R.L. 1980. Classification of the Diplopoda. Muséum national d'histoire naturelle, Paris.

Hoffman R.L. 1982. Diplopoda. In: Parker S.P. (ed.) Synopsis and Classification of Living Organisms Vol. 2: 689-724. McGraw-Hill, New York.

Iniesta L.F.M. \& Ferreira R.L. 2013a. The first troglobitic Pseudonannolene from Brazilian iron ore caves (Spirostreptida: Pseudonannolenidae). Zootaxa 3669 (1): 85-95. https://doi.org/10.11646/zootaxa.3669.1.9

Iniesta L.F.M. \& Ferreira R.L. 2013b. Two new species of Pseudonannolene Silvestri, 1895 from Brazilian iron ore caves (Spirostreptida: Pseudonannolenidae). Zootaxa 3716 (1): 75-80.

https://doi.org/10.11646/zootaxa.3716.1.6

Jeekel C.A.W. 1963. Diplopoda of Guiana. Studies on the Fauna of Suriname and other Guyanas 4 (1): $1-157$.

Jeekel C.A.W. 1985. The distribution of the Diplocheta and the "lost" continent Pacifica (Diplopoda). Bijdragen tot de Dierkunde 55 (1): 100-112.

Jeekel C.A.W. 2004. A bibliographic catalogue of the 'Cambaloidea' (Diplopoda, Spirostreptida). Myriapod Memoranda 7: 43-109.

Jell P.A. 1983. An Early Jurassic millipede from the Evergreen Formation in Queensland. Alcheringa 7 (3): 195-199. https://doi.org/10.1080/03115518308619618 
Jiang X., Shear W.A., Hennen D.A., Chen H. \& Xie Z. 2019. One hundred million years of stasis: Siphonophora hui sp. nov., the first Mesozoic sucking millipede (Diplopoda: Siphonophorida) from mid-Cretaceous Burmese amber. Cretaceous Research 97: 34-39.

https://doi.org/10.1016/j.cretres.2019.01.011

Jiang X.K., Zhang Z., Chen H.M. \& Xie Z. 2021. Description of Hypocambala zizhongi sp. nov. and the new combination, Glyphiulus polytrichus (Golovatch et al., 2011) comb. nov., based on morphological and molecular data (Spirostreptida: Cambalidea: Cambalopsidae). Zootaxa 4903 (3): 405-418.

https://doi.org/10.11646/zootaxa.4903.3.6

Kenrick P., Wellman C.H., Schneider H. \& Edgecombe G.D. 2012. A timeline for terrestrialization. Consequences for the carbon cycle in the Palaeozoic. Philosophical Transactions of the Royal Society $B$ 367 (1588): 519-536. https://doi.org/10.1098/rstb.2011.0271

Korsós Z. \& Johns P.M. 2009. Introduction to the taxonomy of Iulomorphidae of New Zealand, with descriptions of two new species of Eumastigonus Chamberlain, 1920 (Diplopoda. Spirostreptida: Epinannolenidea). Zootaxa 2065 (1): 1-24. https://doi.org/10.11646/zootaxa.2065.1.1

Likhitrakarn N., Golovatch S.I., Thach P., Chhuoy S., Ngor P.B., Srisonchai R., Sutcharit C. \& Panha S. 2020. Two new species of the millipede genus Plusioglyphiulus Silvestri, 1923 from Cambodia (Diplopoda, Spirostreptida). ZooKeys 938: 137-151. http://doi.org/10.3897/zookeys.938.51234

Limaye A. 2012. Drishti: a volume exploration and presentation tool. Proceedings SPIE 8506 Developments in X-Ray Tomography VIII: 85060X. https://doi.org/10.1117/12.935640

Liu W., Rühr P.T. \& Wesener T. 2017. A look with $\mu$ CT technology into a treasure trove of fossils. The first two fossils of the millipede order Siphoniulida discovered in Cretaceous Burmese amber (Myriapoda, Diplopoda). Cretaceous Research 74: 100-108. http://doi.org/10.1016/j.cretres.2017.01.009

Loomis H.F. 1938. The cambaloid millipeds of the Unites States, including a family new to the fauna and new genera and species. Proceedings of the United States National Museum 86 (3043): 27-66.

https://doi.org/10.5479/si.00963801.86-3043.27

Martynov A.V. 1936. O nekotorykh novykh materialakh chelenistonogikh zhivotnykh iz Kuznetskogo Basseina. Izvestiia Akademii nauk SSSR, Seriia Biologicheskaia 6: 1258-1260.

Mauriès J.P. 1977. Le genre Glyphiulus Gervais, 1847, et sa place dans la classification des Cambalides, à propos de la description d'une nouvelle espèce du Viêt-Nam (Diplopoda, Iulida, Cambalidea). Bulletin du Muséum national d'histoire naturelle 301 (431): 237-242.

Mauriès J.P. 1983. Cambalides nouveaux et peu connus d'Asie, d'Amérique et d'Océanie. I. Cambalidae et Cambalopsidae (Myriapoda: Diplopoda). Bulletin du Muséum national d'histoire naturelle. Section A, Zoologie, Biologie et Écologie animales 4 (5): 247-276.

Mauriès J.P. 1987. Cambalides nouveaux et peu connus d'Asie, d'Amérique et d'Océanie. II. Pseudonannolenidae, Choctellidae (Myriapoda, Diplopoda). Bulletin du Muséum national d'histoire naturelle. Section A, Zoologie, Biologie et Écologie animales 9 (1): 169-199.

Mauriès J.P. 1992. Sur la vraie place du genre Protosilvestria Handschin dans la classification des Diplopodes Iuliformes. Berichte des Naturwissentschaftlich-Medizinischen Vereins in Innsbruck 10: 23-31.

Moritz L. \& Wesener T. 2019. The first known fossils of the Platydesmida — an extant American genus in Cretaceous amber from Myanmar (Diplopoda: Platydesmida: Andrognathidae). Organisms Diversity \& Evolution 19 (3): 423-433. https://doi.org/10.1007/s13127-019-00408-0

Mulleried F.K.G. 1942. Fosiles raros de México. I. El primer miriapodo fosil de México, encontrado en el estado de Puebla. Anales de Instituto de Biologia 13: 711-717.

O'Leary M.A. \& Kaufman S. 2011. MorphoBank: phylophenomics in the "cloud". Cladistics 27 (5): 529-537. https://doi.org/10.1111/j.1096-0031.2011.00355.x 
MORITZ L. \& WESENER T., Electrocambalidae, a new millipede family from Cretaceous amber

Pocock R.I. 1887. On the classification of the Diplopoda. Journal of Natural History 20 (118): 283-295. https://doi.org/10.1080/00222938709460057

Rasnitsyn A.P. \& Golovatch S.I. 2004. The identity of Phryssonotus burmiticus (Cockerell, 1917) (Diplopoda, Polyxenida, Synxenidae) in Cretaceous amber from Myanmar. Journal of Systematic Palaeontology 2 (2): 153-157. https://doi.org/10.1017/S1477201904001233

Reboleira A., Hosseini M.J.M., Sadeghi S. \& Enghoff H. 2015. Highly disjunct and highly infected millipedes - a new cave-dwelling species of Chiraziulus (Diplopoda. Spirostreptida: Cambalidae) from Iran and notes on Laboulbeniales ectoparasites. European Journal of Taxonomy 146: 1-18. https://doi.org/10.5852/ejt.2015.146

Santiago-Blay J.A. \& Poinar G.O. 1992. Millipeds from Dominican amber, with the description of two new species (Diplopoda. Siphonophoridae) of Siphonophora. Annals of the Entomological Society of America 85 (4): 363-369. https://doi.org/10.1093/aesa/85.4.363

Schubart O. 1966. Chapter I. Diplopoda III: Pselaphognatha, Opisthospermophora, Colobognatha. In: Hanström B., Brinck P. \& Rudebeck G. (eds) South African Animal Life. Results of the Lund University Expedition in 1950-1951. Vol. 12: 9-227. Swedish Natural Science Research Council, Stockholm.

Selden P. \& Read H. 2007. The oldest land animals: Silurian millipedes from Scotland. Bulletin of the British Myriapod \& Isopod Group 23: 36-37.

Shear W.A. \& Edgecombe G.D. 2010. The geological record and phylogeny of the Myriapoda. Arthropod Structure \& Development 39 (2): 174-190. https://doi.org/10.1016/j.asd.2009.11.002

Shear W.A. \& Kukalová-Peck J. 1990. The ecology of Paleozoic terrestrial arthropods: the fossil evidence. Canadian Journal of Zoology 68 (9): 1807-1834. https://doi.org/10.1139/z90-262

Shear W.A., Selden P.A. \& Gall J.-C. 2009. Millipedes from the Grès à Voltzia, Triassic of France, with comments on Mesozoic millipedes (Diplopoda. Helminthomorpha: Eugnatha). International Journal of Myriapodology 2 (1): 1-13. https://doi.org/10.1163/187525409X462395

Shelley R.M. 2003. A revised, annotated, family-level classification of the Diplopoda. Arthropoda Selecta 11 (3): 187-207.

Shelley R.M. 2007. Taxonomy of extant Diplopoda (millipeds) in the modern era. Perspectives for future advancements and observations on the global diplopod community (Arthropoda: Diplopoda). Zootaxa 1668 (1): 343-362. https://doi.org/10.11646/zootaxa.1668.1.18

Shelley R.M. \& Golavatch S.I. 2011. Atlas of myriapod biogeography. I. Indigenous ordinal and supraordinal distributions in the Diplopoda. Perspectives on taxon origins and ages, and a hypothesis on the origin and early evolution of the class. Insecta Mundi 158: 1-134.

Shi G., Grimaldi D.A., Harlow G.E., Wang J., Wang J., Yang M., Lei W., Li Q. \& Li X. 2012. Age constraint on Burmese amber based on U-Pb dating of zircons. Cretaceous Research 37: 155-163.

https://doi.org/10.1016/j.cretres.2012.03.014

Sierwald P. \& Bond J.E. 2007. Current status of the myriapod class Diplopoda (millipedes). Taxonomic diversity and phylogeny. Annual Review of Entomology 52: 401-420.

https://doi.org/10.1146/annurev.ento.52.111805.090210

Sierwald P., Shear W.A., Shelley R.M. \& Bond J.E. 2003. Millipede phylogeny revisited in the light of the enigmatic order Siphoniulida. Journal of Zoological Systematics and Evolutionary Research 41 (2): 87-99. https://doi.org/10.1046/j.1439-0469.2003.00202.x

Stoev P., Moritz L. \& Wesener T. 2019. Dwarfs under dinosaur legs: a new millipede of the order Callipodida (Diplopoda) from Cretaceous amber of Burma. ZooKeys 841: 79-96.

http://doi.org/10.3897/zookeys.841.34991 
Su Y., Cai C., \& Huang D. 2020. Revision of Phryssonotus burmiticus (Diplopoda, Polyxenida, Synxenidae) in mid-Cretaceous amber from Myanmar. Cretaceous Research 93: 216-224. https://doi.org/10.1016/j.cretres.2018.09.002

Verhoeff K.W. 1910. Über Diplopoden 11.-15. Aufsatz (31.-35.). Beiträge zur Kenntnis der Glomeriden, Juliden, Ascospermorpha und Lysiopetaliden, sowie zur Fauna Siziliens, Untersuchungen über Art- und Gruppensystematik, Morphologie, nachembryonale Entwicklung, Biologie und Geographie. Nova Acta 92 (2): 18-310.

Verhoeff K.W. 1924. Results of Dr. E. Mjöberg's Swedish Scientific Expeditions to Australia 1910-1913. 34. Myriapoda. Diplopoda. Arkiv för Zoologi 16 (5): 1-142.

Verhoeff K.W. 1928-1932. Dr. H.G. Bronn's Klassen und Ordnungen des Tier-Reichs wissentschaftlich dargestellt in Wort und Bild. 5 (II) 2. Gliederfüssler. Arthropoda. Klasse Diplopoda. Akademische Verlagsgesellschaft, Leipzig.

Wesener T. \& Moritz L. 2018. Checklist of the Myriapoda in Cretaceous Burmese amber and a correction of the Myriapoda identified by Zhang (2017). Check List 14: 1131-1140. https://doi.org/10.15560/14.6.1131

Wilde F., Ogurreck M., Greving I., Hammel J.U., Beckmann F., Hipp A., Lottermoser L., Khokhriakov I., Lytaev P., Dose T., Burmester H., Müller M. \& Schreyer A. 2016. Micro-CT at the imaging beamline P05 at PETRA III. AIP Conference Proceedings 1741: 030035. https://doi.org/10.1063/1.4952858

Wilson H.M. \& Anderson L.I. 2004. Morphology and taxonomy of Paleozoic millipedes (Diplopoda: Chilognatha: Archipolypoda) from Scotland. Journal of Paleontology 78 (1): 169-184.

https://doi.org/10.1666/0022-3360(2004)078\%3C0169:MATOPM\%3E2.0.CO;2

Yushkevich P.A., Piven J., Hazlett H.C., Smith R.G., Ho S., Gee J.C. \& Gerig G. 2006. User-guided 3D active contour segmentation of anatomical structures: significantly improved efficiency and reliability. NeuroImage 31 (3): 1116-1128. https://doi.org/10.1016/j.neuroimage.2006.01.015

Wilson H. 2006. Juliformian millipedes from the Lower Devonian of Euamerica: Implications for the timing of millipede cladogenesis in the Paleozoic. Journal of Paleontology 80 (4): 638-649.

http://doi.org/10.1666/0022-3360(2006)80[638:JMFTLD]2.0.CO;2

Manuscript received: 30 December 2020

Manuscript accepted: 4 March 2021

Published on: 17 June 2021

Topic editor: Christian de Muizon

Desk editor: Radka Rosenbaumová

Printed versions of all papers are also deposited in the libraries of the institutes that are members of the EJT consortium: Muséum national d'histoire naturelle, Paris, France; Meise Botanic Garden, Belgium; Royal Museum for Central Africa, Tervuren, Belgium; Royal Belgian Institute of Natural Sciences, Brussels, Belgium; Natural History Museum of Denmark, Copenhagen, Denmark; Naturalis Biodiversity Center, Leiden, the Netherlands; Museo Nacional de Ciencias Naturales-CSIC, Madrid, Spain; Real Jardín Botánico de Madrid CSIC, Spain; Zoological Research Museum Alexander Koenig, Bonn, Germany; National Museum, Prague, Czech Republic. 